\title{
Erratum to: Cisplatin-induced mesenchymal stromal cells-mediated mechanism contributing to decreased antitumor effect in breast cancer cells
}

Svetlana Skolekova ${ }^{1}$, Miroslava Matuskova ${ }^{1}$, Martin Bohac ${ }^{2}$, Lenka Toro ${ }^{1}$, Erika Durinikova ${ }^{1}$, Silvia Tyciakova ${ }^{1}$, Lucia Demkova', Jan Gursky ${ }^{3}$ and Lucia Kucerova ${ }^{1 *}$

Unfortunately, after publication of this article [1] it was noticed that 2 authors were not listed. The corrected author list can be seen above and the corrected Authors' Contributions and Acknowledgements sections are included below.

\begin{abstract}
Authors' contributions
Concept, design and development of methodology: LK, MM; RFP vector design and RFP-MSC preparation ST, ED; acquisition of data LK, SS, MM, LT, $L D$, JG; analysis and interpretation of data LK, MM, SS, LT, LD, JG; writing of the manuscript and review: LK, SS; patient material and patient management: MB. All authors read and approved the final manuscript.
\end{abstract}

\section{Acknowledgements}

We thank M. Dubrovcakova, V. Frivalska for the excellent technical assistance and B. Smolková, PhD. for help with statistic analysis. We thank L. Skirkova for technical help with vector preparation. This study was supported by the VEGA grants No.2/0087/15 (L.K.) and 2/0171/13 (M.M.). This work was supported by the Slovak Research and Development Agency under the contract No.APV-0230-11 and No.APV-0052-12. The experiments on the IncuCyte $\mathrm{ZOOM}^{\mathrm{TM}}$ were enabled with the kind help and the financial support from the Cancer Research Foundation.

\section{Author details \\ ${ }^{1}$ Laboratory of Molecular Oncology, Cancer Research Institute, Slovak Academy of Sciences, Vlarska 7, 83391 Bratislava, Slovak Republic. ${ }^{2}$ Department of Plastic, Aesthetic and Reconstructive Surgery, University Hospital, Bratislava, Slovakia. ${ }^{3}$ Institute of Molecular and Translational Medicine, Faculty of Medicine and Dentistry, Palacky University Olomouc, Hnevotinska 5, Olomouc, Czech Republic.}

Received: 18 February 2016 Accepted: 18 February 2016 Published online: 25 February 2016

\section{Reference}

1. Skolekova S, Matuskova M, Bohac M, Toro L, Demkova L, Gursky J, Kucerova L. Cisplatin-induced mesenchymal stromal cells-mediated mechanism contributing to decreased antitumor effect in breast cancer cells. Cell Commun Signal. 2016;14:4.

\footnotetext{
* Correspondence: lucia.kucerova@savba.sk

'Laboratory of Molecular Oncology, Cancer Research Institute, Slovak Academy of Sciences, Vlarska 7, 83391 Bratislava, Slovak Republic
}

\footnotetext{
Submit your next manuscript to BioMed Central and we will help you at every step:

- We accept pre-submission inquiries

- Our selector tool helps you to find the most relevant journal

- We provide round the clock customer support

- Convenient online submission

- Thorough peer review

- Inclusion in PubMed and all major indexing services

- Maximum visibility for your research
}

Submit your manuscript at www.biomedcentral.com/submit
C 2016 Skolekova et al. Open Access This article is distributed under the terms of the Creative Commons Attribution 4.0 International License (http://creativecommons.org/licenses/by/4.0/), which permits unrestricted use, distribution, and reproduction in any medium, provided you give appropriate credit to the original author(s) and the source, provide a link to the Creative Commons license, and indicate if changes were made. The Creative Commons Public Domain Dedication waiver (http://creativecommons.org/publicdomain/zero/1.0/) applies to the data made available in this article, unless otherwise stated. 